\title{
MILK PROTEINS-DERIVED BIOACTIVE PEPTIDES IN DAIRY PRODUCTS: MOLECULAR, BIOLOGICAL AND METHODOLOGICAL ASPECTS*
}

\author{
Bartłomiej Dziuba ${ }^{1 凶}$, Marta Dziuba $^{2}$ \\ ${ }^{1}$ Department of Industrial and Food Microbiology, University of Warmia and Mazury in Olsztyn \\ Plac Cieszyński 1, 10-957 Olsztyn, Poland \\ 2Department of Food Biochemistry, University of Warmia and Mazury in Olsztyn \\ Plac Cieszyński 1, 10-957 Olsztyn, Poland
}

\begin{abstract}
Proteins are one of the primary components of the food, both in terms of nutrition and function. They are main source of amino acids, essential for synthesis of proteins, and also source of energy. Additionally, many proteins exhibit specific biological activities, which may have effect on functional or pro-health properties of food products. These proteins and their hydrolysis products, peptides, may influence the properties of food and human organism. The number of commercially available food products containing bioactive peptides is very low, apart from that milk proteins are their rich source. It could be supposed that number of available products with declared activity will rise in near future because of observed strong uptrend on interest in such products. Molecular and biological properties of milk proteins, as precursors of bioactive peptides was characterised in the work. Therefore, the strategy of research and obtaining of such peptides both in laboratory and industrial scale, as well as the range of their commercial application, was presented. Several examples of research efforts presenting high potential to develop new products containing bioactive peptides from milk proteins and predetermined as nutraceuticals was described.
\end{abstract}

Key words: milk proteins, bioactive peptides, hydrolysis, products with bioactive peptides

\section{INTRODUCTION}

Research into bioactive peptides began in the 1950s. Initially, researchers and technology experts focused their attention on peptides that activate taste receptors. In 1978, Yamasaki and Maekawa [1978] isolated the "delicious peptide" from papain-hydrolysed beef which gives broth its characteristic "meaty" taste (umami/savory). The above authors relied on gel filtration, ion-exchange chromatography, filter paper electrophoresis and Edman degradation to determine the peptide's sequence: H-Lys-Gly-Asp-Glu-Glu-Ser-Leu-Ala-OH. They also demonstrated that selected fragments of that peptide taste umami, sour, salty, bitter or sweet. Therefore fragments of the analysed peptide delivered wide bouquet of taste sensations. Research into peptides expands our knowledge of the correlations between health and diet. Nutrition plays a key role in the prevention of various diseases, and it optimizes health and well-being [Mils et al. 2011].

\footnotetext{
凶bartlomiej.dziuba@uwm.edu.pl

*This work has been financed from grant No. NN 312484240 of the National Science Centre, Poland. 
Those observations contributed to the emergence of functional foods - products that provide health benefits in addition to basic nutrition. The functional food market abounds in dairy products, including fermented milk products containing lactic acid bacteria which have probiotic properties [Fuller 1989] and produce secondary metabolites that deliver health benefits [Stanton et al. 2005]. Milk is a rich source of bioactive substances with beneficial effects for humans [Expósito and Recio 2006, Korhonen and Pihlanto 2006, Mils et al. 2011, Phelan et al. 2009]. Milk protein derivatives are physiologically active peptides which are released in the digestive tract [Chabance et al. 1998, Ferranti et al. 2004, Meisel and Frister 1989, Parrot et al. 2003, Svedberg et al. 1985]. $\beta$-casomorphins and casein phosphopeptides (CPP) are produced in vivo after the consumption of dairy products, including milk, fermented milk, cheese and yogurt [Chabance et al. 1998, Hernández-Ledesma et al. 2004, Kasai et al. 1992, Meisel and Frister 1989, Parrot et al. 2003, Svedberg et al. 1985]. Food proteins and peptides are hydrolysed at different stages: ingestion, digestion and absorption [Shimizu 2004, Vermeirssen et al. 2004]. The exact amount of a peptide that can be released and activated during the consumption of a balanced diet remains unknown because proteolytic enzymes are characterised by varied specificity, therefore, the range of bioactive fragments released from a precursor protein cannot be accurately predicted [Dziuba and Darewicz 2007, Dziuba et al. 2006, Phelan et al. 2009]. The presence of bioactive peptides in dairy products such as cheese, fermented milk and yoghurt has been reported in numerous research studies [FitzGerald et al. 2004, Gagnaire 2001, Gobbetti et al. 2002, Korhonen and Pihlanto 2006, Meisel et al. 1997, Nakamura et al. 1995, Saito et al. 2000].

The choice of commercially available foods containing bioactive peptides, derivatives of milk proteins and other proteins, is limited. Bioactive peptides are a rapidly developing field of research which should significantly contribute to the availability of functional foods on the market in the near future. The molecular and biological properties of milk proteins as precursors of bioactive peptides have been described in this study. The protocols for synthesizing and analysing bioactive peptides in a laboratory and in industrial applications have been discussed. Research studies suggesting that bioactive peptides from milk proteins can be used in the production of nutraceuticals have been overviewed.

\section{FOOD PRODUCTS AS A COMPLEX MOLECULAR SYSTEM}

New methods supporting the isolation and identification of chemical compounds in food ingredients and products, including proteins and peptides, are being constantly developed. In the process of designing high-quality products, food technologists analyse the correlations between the product's quality and its molecular structure, defined as a molecular system with a specific, hierarchical molecular composition and molecular interactions. The structural and functional hierarchy of chemical compounds found in food ingredients and products accounts for their increasing molecular complexity [Dziuba and Dziuba 2009, 2010, Eads 1994]. Interactions that shape the structure and properties, including functional properties, of foods and ingredients are observed at every level of their organisational structure. The molecular structure of chemical compounds in foods is described by a chemical formula (which is often limited to the number and type of atoms), configuration (arrangement of atoms in a monomer), sequence (sequence of monomer residues in polymers), conformation (rotation angles between bonds), secondary, tertiary and quarternary structure, energy levels of electrons, mobility (distribution of energy between translational, rotational and vibrational degrees of freedom), range and type of molecular interactions (geometry, intermolecular forces) and selected macromolecule fragments with different functions (functional motifs and domains). Many domains have a unique spatial structure and, subject to context, they can be regarded as functional, as well as structural elements. As molecular systems, food ingredients and products contain structures that differ in size by 15 orders of magnitude - from subatomic particles (the diameter of the atomic nucleus is approximately $10^{-15} \mathrm{~m}$ ) to macroscopic structures (muscles can have the length of $1 \mathrm{~m}$ ). The time (duration) of molecular-level processes during which functional properties are shaped can differ by 22 orders of magnitude - from femtoseconds (photon absorption time) to a year (sugar crystallization). 
The strength of internal and external (applied) forces at different structural levels of a food product, a dynamic and multiphase system, can also differ by more than 10 orders of magnitude. A sound knowledge of the structure and functions of chemical compounds is required in the process of designing functional foods. The interactions between different ingredients have to be taken into account in structural and functional analyses.

\section{NOMENCLATURE AND MOLECULAR PROPERTIES OF MILK PROTEINS}

In the living world, various protein systems are synthesized through the formation of monomer subunit associations. Those associations have a fixed structure, and they comprise several identical or different subunits or many identical subunits. Casein and whey proteins make up the protein system of milk. Whey protein molecules have a globular structure with a relatively high content of helical structures and a balanced distribution of acidic and basic amino acid residues and hydrophobic and hydrophilic amino acid residues along the polypeptide chain [Madureira et al. 2007]. In comparison with standard globular proteins such as whey proteins, casein is characterised by a unique, amphiphilic structure [Swaisgood 1992]. This characteristic feature can be observed in the structure of monomeric subunits of the major forms of casein which contain fragments of hydrophilic and hydrophobic protein molecules. Milk casein comprises large, porous and spherical particles which are known as casein micelles. Casein micelles differ from other protein systems for various reasons. Firstly, despite their large size and fixed structure, casein micelles are characterised by significant variability. The smallest micelles with the diameter of around $25 \mathrm{~nm}$ comprise approximately 450 monomeric subunits, whereas the largest micelles with a diameter greater than $150 \mathrm{~nm}$ can contain more than 10,000 monomeric subunits [Waugh 1971]. Secondly, even such a high number of monomeric subunits aggregates in an orderly fashion to create micelles from non-identical monomeric subunits of the four major forms of casein: $\alpha_{\mathrm{s} 1}, \alpha_{\mathrm{s} 2}, \beta$ and $\mathrm{\kappa}$ [Dziuba 1986]. The properties of micellar casein and whey proteins largely determine the behavior of milk during technological processes such as pasteurization, sterilization, condensation and cheese curd formation. Those properties can be attributed to the specific structure of milk proteins and structural changes that take place during processing. A sound knowledge of the structure of milk proteins and structural changes induced by processing is required for designing new production technologies and analysing dairy products.

Milk proteins have been defined and classified by the American Dairy Science Association Committee on the Nomenclature, Classification, and Methodology of Milk Proteins [Farrell et al. 2004]. The relevant information is continuously updated. Casein is defined as a phosphoprotein which is precipitated at the temperature of $20^{\circ} \mathrm{C}$ from raw skimmed milk acidified to the $\mathrm{pH}$ of 4.6. Based on the results of electrophoretic separation and evaluations of amino acid sequence homology in different casein fractions, four major families of casein have been identified: $\alpha_{\mathrm{s} 1}, \alpha_{\mathrm{s} 2}$, $\beta$ and $\kappa$.

The $\boldsymbol{\alpha}_{\mathrm{s} 1}$-casein family, which makes up to $40 \%$ of all casein fractions in bovine milk, contains one primary component and one secondary component (in smaller quantities). Both proteins are built of single polypeptide chains with the same amino acid sequence but different degrees of phosphorylation [Eigel et al. 2006, Mercie et al. 1971]. The secondary component contains the ninth additional phosphoserine residue. The reference protein for the $\alpha_{\mathrm{s} 1}$-casein family is $\alpha_{\mathrm{s} 1}$-casein, genetic variant $\mathrm{B}-8 \mathrm{P}$ whose polypeptide chain contains 199 amino acid residues. Seven genetic variants of this casein have been identified to date: A, B, C, D, E, F, G and H [Farrell et al. 2004, Grosclaude and Ribadeau-Dumas 1973, Mercie et al. 1971]. The differences between the above genetic variants and the genetic variants of the remaining casein families result from the deletion or genetically controlled substitution of amino acids. The degree of association of $\alpha_{\mathrm{s} 1}$-casein fractions is determined by ionic strength (salt concentrations in a solution): tetrameters are formed in solutions with salt concentrations below $0.1 \mathrm{M}$, octamers - in solutions with salt concentrations of 0.1 to 0.4 , whereas in solutions with salt concentrations higher than $0.5 \mathrm{M}, \alpha_{\mathrm{s} 1}$-casein becomes insoluble (is salted out).

The $\boldsymbol{\alpha}_{\mathrm{s} 2}$-casein family is more complex. It accounts for up to $10 \%$ of all casein fractions in bovine milk, and it is represented by two primary components 
and several secondary components. The reference protein for the $\alpha_{\mathrm{s} 2}$-casein family is $\alpha_{\mathrm{s} 2}$-casein, genetic variant A-11P whose polypeptide chain contains 207 amino acid residues and a single intramolecular disulfide bond [Swaisgood 1992]. Four genetic variants of $\alpha_{\mathrm{s} 2}$-casein have been identified to date: A, B, C and D [Brignon and Ribadeau-Dumas 1973, Grosclaude 1979, Mahè and Grosclaude 1982]. Fractions of $\alpha_{\mathrm{s}_{2}}$ -casein are more sensitive to $\mathrm{Ca}^{2+}$ concentrations than $\alpha_{\mathrm{s} 1}$-casein fractions, and they are precipitated in the presence of $2 \mathrm{mM} \mathrm{Ca}^{2+}$ [Farrell et al. 2004].

The $\boldsymbol{\beta}$-casein family, which makes up to $45 \%$ of all casein fractions in bovine milk, combines many fractions, including the products of partial hydrolysis of the major $\beta$-casein fraction by milk plasmin [Farrell et al. 2004]. This process gives rise to $\gamma_{1}, \gamma_{2}$ and $\gamma_{3}$-casein fractions which constitute fragments 29-209, 106-209 and 108-209 of $\beta$-casein, respectively. The $\beta$-casein family also comprises polypeptides, components 5, 8-slow and 8-fast of the proteose-peptone fraction, which correspond to fragments 1-105 or 1-107, 1-28, and 29-105 of $\beta$-casein, respectively. The reference protein for this family is $\beta$-casein, genetic variant $\mathrm{A}^{2}-5 \mathrm{P}$ whose polypeptide chain contains 209 amino acid residues, excluding the Cys residue. Twelve genetic variants of $\beta$-casein have been identified to date: $\mathrm{A}^{1}, \mathrm{~A}^{2}, \mathrm{~A}^{3}, \mathrm{~B}, \mathrm{C}, \mathrm{D}, \mathrm{E}, \mathrm{F}, \mathrm{G}, \mathrm{H}^{1}, \mathrm{H}^{2}$ and I [Dong and Ng-Kwai-Hang 1998, Han et al. 2000, Swaisgood 1982, Visser et al. 1995, Waugh 1971]. In isolated systems, $\beta$-casein aggregates to form "micelles" with association number 20 (five connected tetramers) at room temperature [Kumosinski et al. 1993].

The к-casein family contains one major sugar-free component and at least six secondary components. Secondary components are characterised by different degrees of phosphorylation ( 0 or 1 phosphate residue) and glycosylation [Farrell et al. 2004]. א-casein accounts for up to $15 \%$ of all casein fractions in bovine milk. The reference protein for this casein family is $\kappa$-casein, genetic variant A-1P whose polypeptide chain contains 169 amino acid residues and one phosphate residue. Eleven genetic variants of $\kappa$-casein have been identified to date: A, B, C, E, F $F^{1}, F^{2}, G^{1}$, $\mathrm{G}^{2}, \mathrm{H}, \mathrm{I}$ and $\mathrm{J}$ [Alexander et al. 1988, Grosclaude et al. 1972, Mercier 1973]. $\kappa$-casein contains up to one phosphate residue, and it is soluble in the presence of calcium ions. $\kappa$-casein molecules can associate with the molecules of $\alpha_{\mathrm{s} 1}, \alpha_{\mathrm{s} 2}$ and $\beta$ casein, and they protect them against precipitation in the presence of calcium ions, which leads to the formation of stable colloidal molecules of micellar casein [Horne 2006]. Isolated $\kappa$-casein polymerizes to form a mixture of dimers to octamers.

Whey proteins are milk proteins which remain in whey after the precipitation of casein. Whey proteins account for around $20 \%$ of all milk proteins [Madureira et al. 2007]. The predominant whey proteins are $\beta$-lactoglobulin $(\beta$-Lg) and $\alpha$-lactalbumin $(\alpha-\mathrm{La})$. Other whey proteins include bovine serum albumin (BSA), immunoglobulins (IG), lactoferrin (BLF), lactoperoxidase (LP) and other.

$\beta$-lactoglobulin is a major whey protein with 11 identified genetic variants: A, B, C, D, E, F, G, H, I, J, W [Brignon et al. 1977, Conti et al. 1988, Godovac-Zimmermann et al. 1996, 1990, Jakob and Puhan 1992]. Variants A and B are most commonly encountered [Jakob and Puhan 1992]. The reference protein for the $\beta$-lactoglobulin family is $\beta$-lactoglobulin, genetic variant $B$ whose polypeptide chain contains 162 amino acid residues [Eigel et al. 1984]. $\beta$-lactoglobulin occurs as a stable dimer at the $\mathrm{pH}$ of 5.2 to 7.0, as a monomer at the $\mathrm{pH}$ of 3.0 and above 8.0, and as an octamer at the $\mathrm{pH}$ of 3.5 to 5.2 [Madureira et al. 2007].

Similarly to $\beta$-lactoglobulin, $\alpha$-lactalbumin is produced in the mammary gland. $\alpha$-lactalbumin participates in the biosynthesis of lactose, and it is an allosteric effector of $\beta$-1,4-galactosyltransferase [Kuhn et al. 1980]. Three genetic variants of $\alpha$-lactalbumin have been identified: A, B and C [Madureira et al. 2007]. Variant B is a reference protein whose polypeptide chain contains 123 amino acid residues. The globular structure of $\alpha$-lactalbumin is stabilised by disulfide bonds at the $\mathrm{pH}$ of 5.4 to 9.0 [Permyakov and Berliner 2000].

Bovine serum albumin is not synthesized in the mammary gland, but it is transferred from blood to milk. A single BSA polypeptide chain contains 582 amino acid residues [Carter and Ho 1994].

Immunoglobulins are protein complexes synthesized by B lymphocytes. They are responsible for immunological functions [Madureira et al. 2007]. 
The remaining whey proteins account for around $0.6 \%$ of total milk proteins and show various types of biological activity.

The therapeutic properties of milk proteins have been investigated by many researchers in the past decades [Madureira et al. 2007, Mils et al. 2011, Zimecki and Kruzel 2007]. Whey proteins contain lactoferrin, $\beta$-lactoglobulin, $\alpha$-lactalbumin and serum albumin, and they were found to inhibit the growth of tumors more effectively than other food proteins [Parodi 2007]. In an acidic environment, $\alpha$-lactalbumin forms the HAMLET (human $\alpha$-lactalbumin made lethal to tumor cells) complex with oleic acid which inhibits the proliferation of various tumors by an apoptosislike mechanism [Svanborg et al. 2003]. The BAMLET complex, the bovine equivalent of HAMLET, has been recently found to exert a strong cytotoxic effect on eight lines of tumor cells by increasing the permeability of the lysosomal membrane [Rammer et al. 2010].

Proteomic research into MFGM (milk fat globule membrane) proteins has been developing rapidly in recent years [Cavaletto et al. 2008, Manso et al. 2005, Reinhardt and Lippolis 2008]. A fatty-acid-bindingprotein isolated from MFGM has been found to inhibit the growth of breast tumor cells [Spitsberg 2005].

\section{MILK PROTEINS AS BIOACTIVE PEPTIDE PRECURSORS COMPLEMENTING THE SYSTEM OF ENDOGENOUS BIOACTIVE PEPTIDES}

Research carried out by numerous scientific centers around the world led to the identification and description of a vast number of biologically active peptides isolated from tissues and fluids of different organisms, including bacteria, fungi, plants and animals. Those peptides are characterised by significant chemical diversity. The discussed group of compounds contains simple dipeptides as well as complex, linear and cyclic oligopeptides and polypeptides which are often modified by posttranslational glycosylation, phosphorylation, acylation or hydroxylation of amino acid residues [Dziuba 2005, Dziuba et al. 1999]. The precursors of many biological active peptides include food proteins. Food protein peptides can lower blood pressure, inhibit the activity of proline-specific endopeptidases, stimulate the immune system, act as opioids and opioid antagonists, contract smooth muscles, inhibit blood platelet aggregation, inhibit HIV proteinase and oxidation processes, demonstrate antibacterial and fungicidal activity and surface activity, bind ions, participate in mineral transport, determine sensory properties, improve the nutritional value of foods and control body weight [Dziuba and Darewicz 2007]. According to the current state of scientific knowledge, in addition to fulfilling its basic roles, every protein can contain fragments that control life processes in various organisms [Karelin et al. 1998]. New, additional criteria have been developed for evaluating proteins as a potential source of biologically active peptides. Those criteria and the protocols for investigating proteins as precursors of bioactive peptides have been discussed in detail in our previous studies [Dziuba et al. 2012, Dziuba and Dziuba 2009], and the relevant information is available in the BIOPEP [Dziuba et al. 2003] online database of proteins and bioactive peptides (http://www.uwm.edu. $\mathrm{pl} /$ biochemia). Potentially biologically active protein fragments with structural motifs corresponding to bioactive peptides remain inactive in precursor protein sequences. When released from the precursor by proteolytic enzymes during technological processing or digestion, those fragments are ingested and absorbed, and they can interact with the corresponding receptors and affect the body's physiological functions. They can thus complement the system of endogenous bioactive peptides. This process is illustrated in the diagram in Figure 1.

Many physiologically active peptides are multifunctional. They play regulatory roles, but also directly influence various developmental and metabolic processes. It should be noted that specific physiological effects are not always manifested when a peptide is administered orally or when it is released by digestive tract enzymes. Peptides, for example milk protein peptides, which play different physiological roles, including opioids and immunostimulants, probably undergo further hydrolysis in the body [Dziuba et al. 2009, Phelan et al. 2009]. 


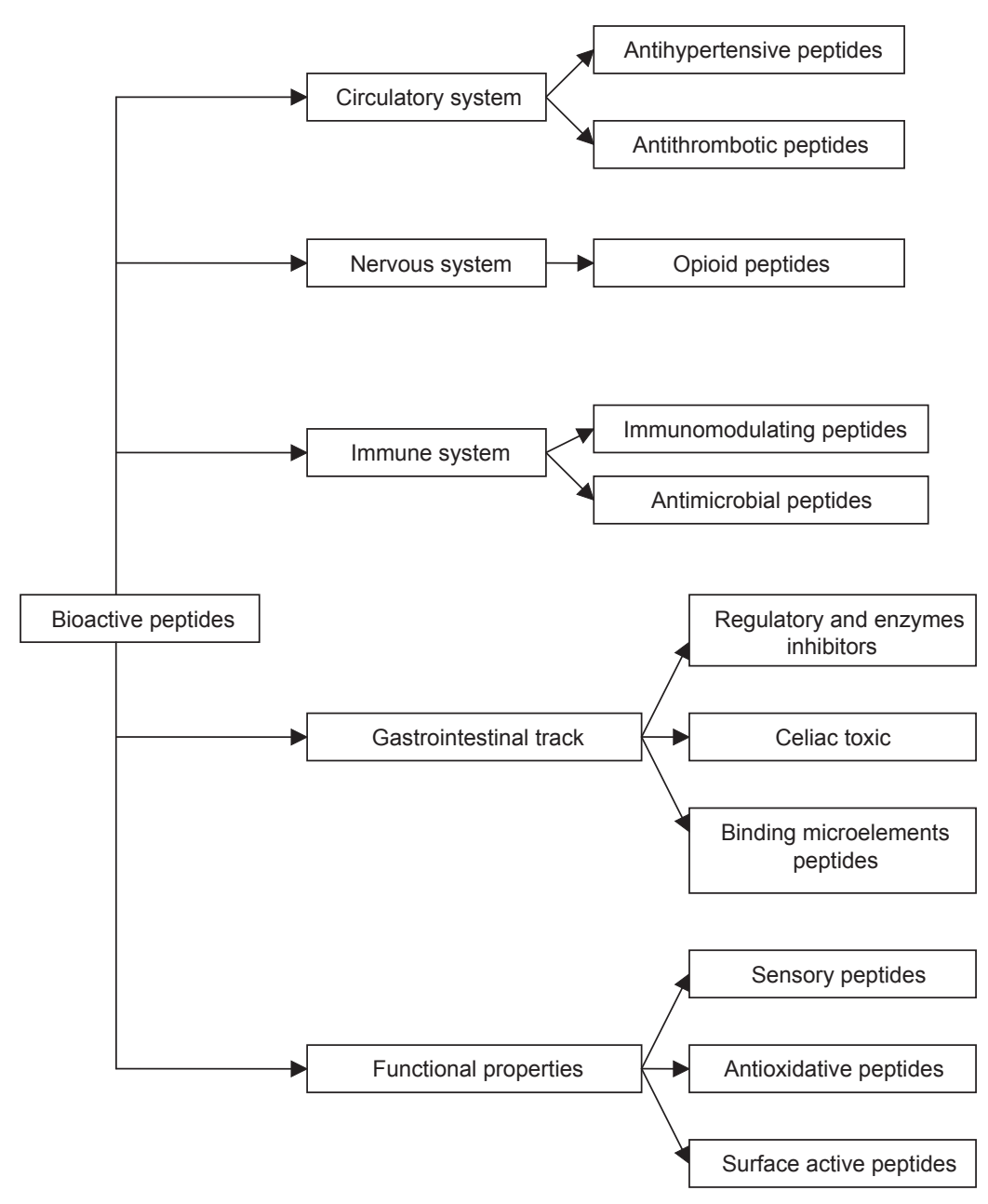

Fig. 1. Function of bioactive peptides from milk proteins

\section{PROFILES OF POTENTIAL BIOLOGICAL ACTIVITY OF MILK PROTEINS}

Every protein sequence can be described based on its profile of potential biological activity and the frequency of motifs representing a given type of potential activity [Dziuba and Dziuba 2009]. The profile of potential biological activity describes the type, number and location of active fragments. The frequency of a bioactive fragment occurrence in the protein sequence is a quantitative measure calculated as the ratio of the number of active fragments to the total number of amino acid residues. Milk proteins are generally a very rich source of bioactive peptides. Major milk proteins as precursors of bioactive peptides are characterised in Table 1 based on BIOPEP data. The differences between genetic variants of milk proteins do not significantly affect their ability to act as precursors of biologically active peptides. Fragments of casein polypeptide chain sequences containing phosphoserine residues participate in the transport and absorption of $\mathrm{Ca}^{+2}$ ions. The following major categories of bioactive peptides have been derived from milk proteins: antihypertensive, antithrombotic, opioid, casein phosphopeptides, antimicrobial, cytomodulatory, immunomodulatory and other [Gautier et al. 2006, Korhonen and Pihlanto 2006, Mils et al. 2011, Phelan et al. 2009, Stuknyte et al. 2011]. 


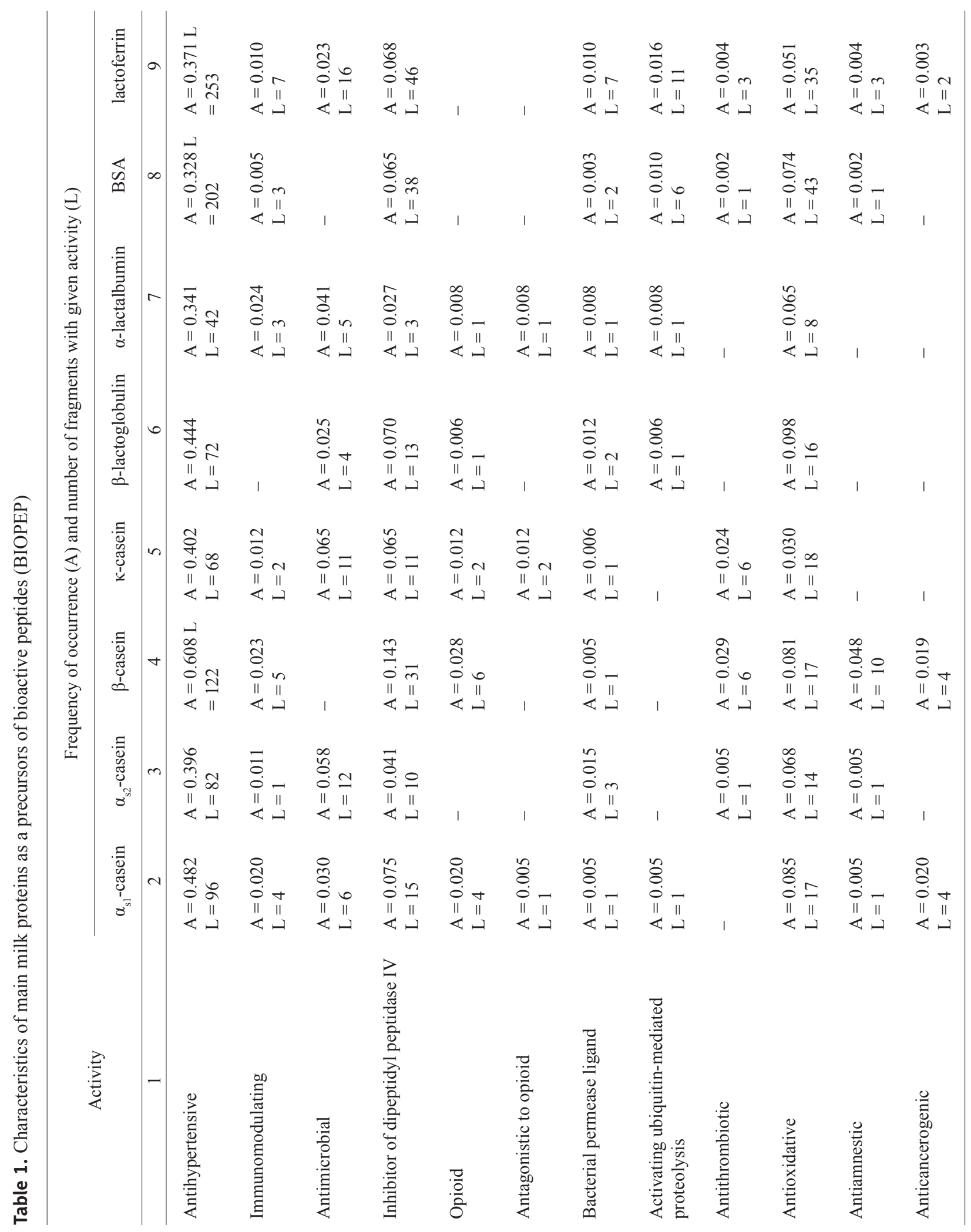




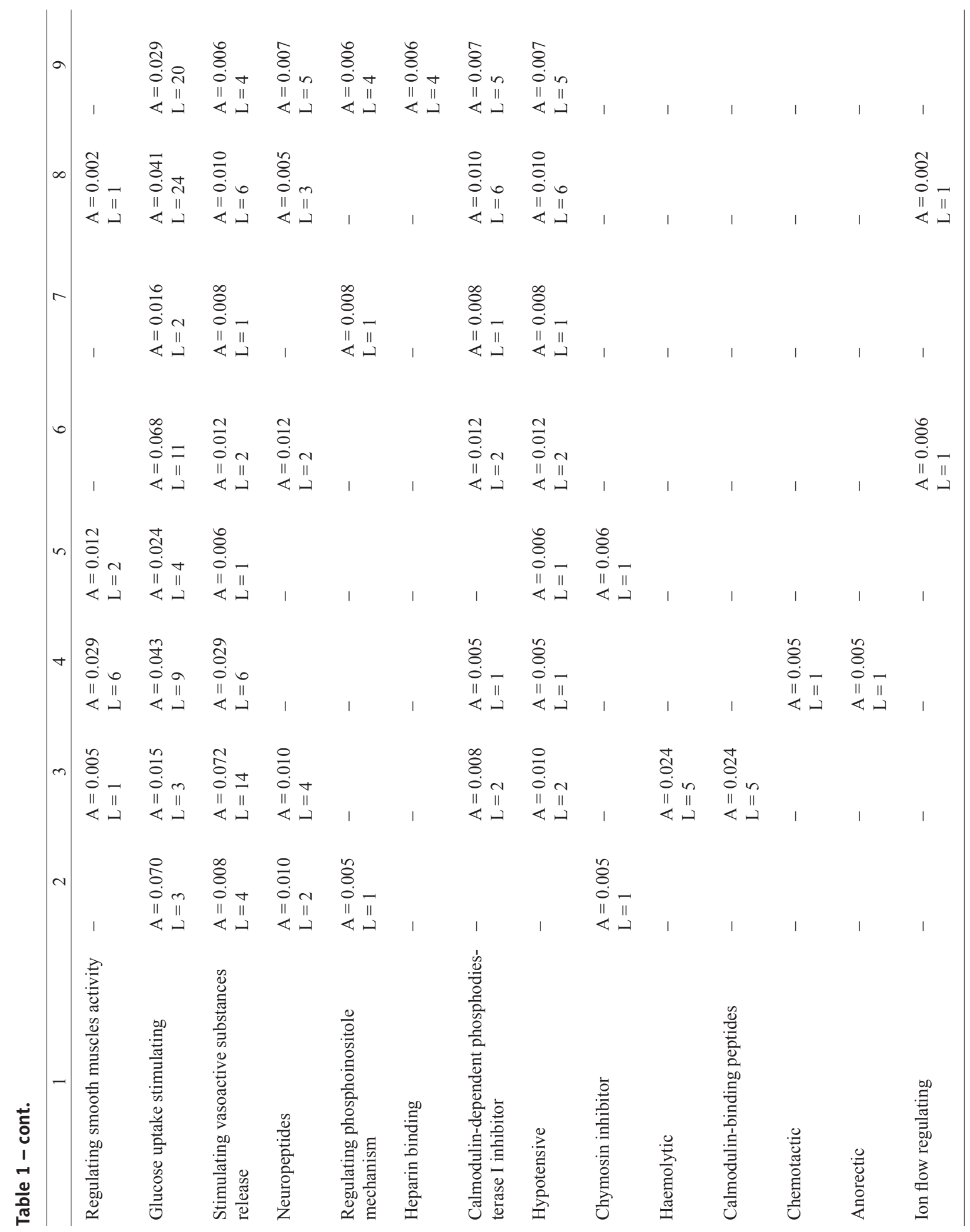




\section{STRATEGY FOR ISOLATING AND ANALYSING BIOACTIVE PEPTIDES}

Scientific advancements expand our knowledge, including the knowledge of food. Continuously improved research methods enable scientists to probe deeper into the nature of matter and natural phenomena. Fundamental barriers between traditional biological sciences are gradually eliminated as research becomes increasingly interdisciplinary. Biochemistry, molecular biology, genetics, immunology, microbiology, food science, physiology, pharmacology and molecular medicine speak the same language and apply the same molecular tools and methods. Despite the above, our ability to answer scientific questions is limited by the current state of knowledge and the possibilities offered by the available methods of scientific inquiry. Various theoretical and experimental methods are used to explain phenomena at different molecular levels. In proteomic and peptidomic research, analytical techniques are combined with computer-aided methods [Carrasco-Castilla et al. 2012] as part of an emerging scientific discipline - bioinformatics. According to the Oxford English Dictionary, bioinformatics is the science of collecting and analysing biological data. The rapid development of computer technology, IT and statistical methods contributed to the development of an extensive system of biological databases and servers [Dziuba et al. 1999, Minkiewicz et al. 2008]. In addition to information about the collected biological compounds, those databases contain tools for comprehensive data analysis. The BIOPEP database offers such solutions. The strategy for analysing proteins and bioactive peptides is shown in Figure 2 [Dziuba and Dziuba 2009]. In the presented solution, computer technology is combined with analytical methods. The results can be used in food research, and they can support the development of new technologies for the production of special purpose foods. The main stages of research into bioactive peptides and precursor proteins include the identification and selection of proteins characterised by the highest frequency of motifs with the given activity [Dziuba and Darewicz 2007], selection of enzymes that release those motifs (in silico proteolysis) [Dziuba et al. 2006], verification of the results of in silico proteolysis by analytical methods [Vecruysse et al. 2009], peptides isolation and purification [Korhonen and Pihlanto 2006],

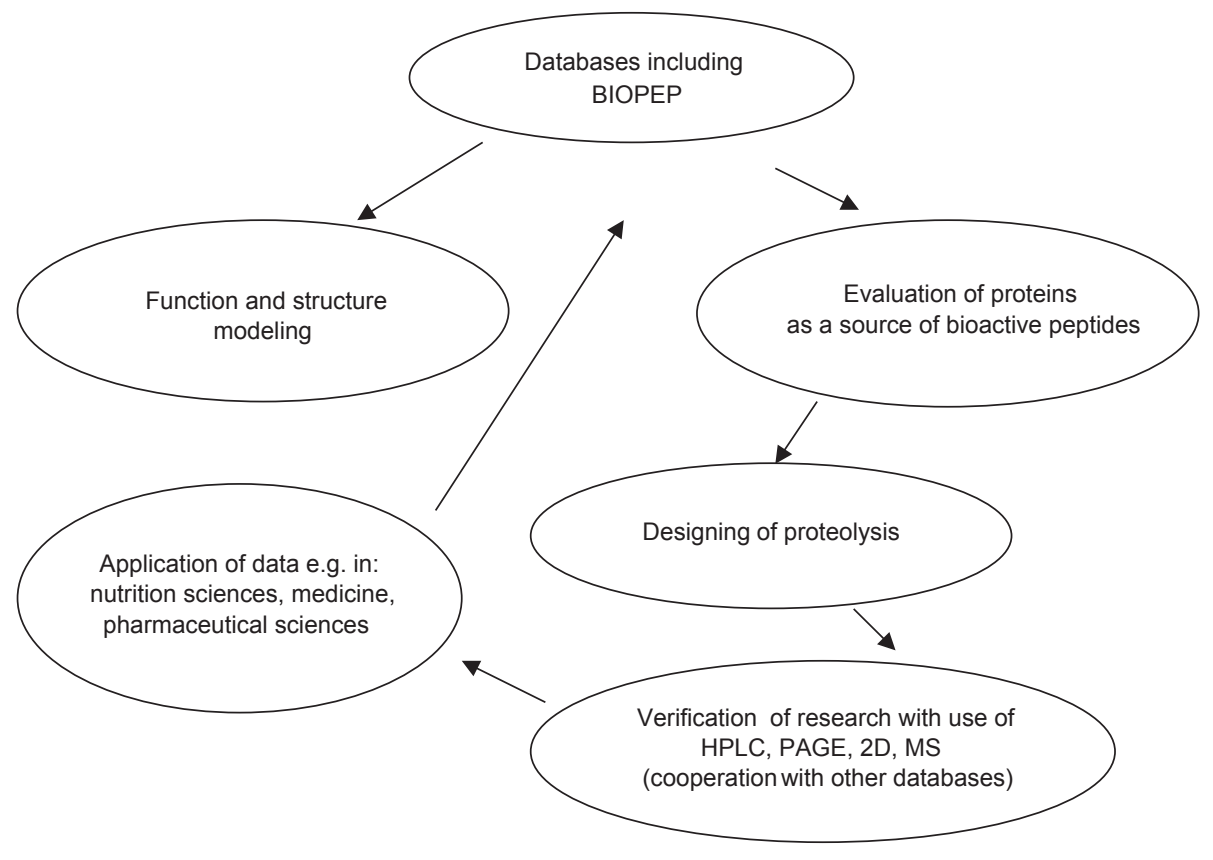

Fig. 2. Research strategy for proteins and bioactive peptides 
application of in vitro methods, followed by ex vivo and in vivo methods in evaluations of biological activity [Expósito and Recio 2006, Simos et al. 2011], and determination of correlations between structure and function [Iwaniak 2011].

The combination of bioinformatics and chemometrics tools speeds up the screening of various peptide sources with high levels of biological activity and optimises the process of isolating (selected substrates) and identifying peptides in food products. The process of identifying and isolating peptides in a laboratory and in industrial applications is overviewed in Table 2 [Carrasco-Castilla et al. 2012, Korhonen and Pihlanto 2006, 2007, Langevin et al. 2012, Minkiewicz and Dziuba 2009].

As a precursor of bioactive peptides, every protein has to undergo proteolysis. Bioactive peptides can be released by enzymes from food precursor proteins during processing (ripening, fermentation, heating), storage and in vitro proteolysis [Korhonen and Pihlanto 2006, Sanlidere Algolu and Őner 2011, Tavares et al.
2011]. Bioactive fragments released in the presence of proteolytic enzymes can constitute an ingredient of a food product or can be isolated by advanced industrial separation methods [Korhonen and Pihlanto 2007]. Bioactive peptides can also be produced by chemical (in an almost non-aqueous phase) and enzymatic synthesis, and with the use of recombinant DNA methods [Minkiewicz and Dziuba 2009]. Synthesis is the most popular method of obtaining bioactive peptides in a laboratory [Narai-Kanayama et al. 2010]. In industrial applications, foods containing bioactive peptides are produced by hydrolysis with the involvement of digestive proteolytic enzymes and proteolytic enzymes of microbiological origin [Korhonen and Pihlanto 2006]. Pepsin and trypsin are commonly applied in enzymatic hydrolysis of proteins. They are generally used to produce ACE inhibitory peptides, namely antihypertensive peptides and calcium-binding phosphopeptides [Adt et al. 2011, FitzGerald et al. 2004]. Other digestive enzymes and combinations of various proteinases, including alcalase, chymotrypsin, pancreatin

Table 2. Production of bioactive peptides at laboratory and industrial scale

\begin{tabular}{|c|c|c|}
\hline Stage & Laboratory scale & Industrial scale \\
\hline Protein source & food proteins & waste products reach in proteins \\
\hline Hydrolysis & $\begin{array}{l}\text { hydrolysis by intestinal enzymes } \\
\text { hydrolysis during food processing } \\
\text { (fermentation, maturation) } \\
\text { hydrolysis with different proteolytic enzymes }\end{array}$ & $\begin{array}{l}\text { hydrolysis with microbial hydrolases } \\
\text { hydrolysis during fermentation } \\
\text { reactors with/without continuous flow } \\
\text { immobilised enzymes }\end{array}$ \\
\hline $\begin{array}{l}\text { Separation } \\
\text { and purification }\end{array}$ & $\begin{array}{l}\text { ultrafiltration membranes } \\
\text { mass exclusion chromatography } \\
\text { ionexchange chromatography } \\
\text { affinity chromatography } \\
\text { high-performance liquid chromatography }\end{array}$ & $\begin{array}{l}\text { ultrafiltration membranes } \\
\text { ionexchange membranes } \\
\text { nanofiltration membranes } \\
\text { electromembranes } \\
\text { ionexchange chromatography }\end{array}$ \\
\hline $\begin{array}{l}\text { Biological activity } \\
\text { assessment }\end{array}$ & in vitro, ex vivo and in vivo research & in vitro methods \\
\hline $\begin{array}{l}\text { Determination } \\
\text { of peptides sequence }\end{array}$ & $\begin{array}{l}\text { edman's degradation } \\
\text { mass spectrometry (API-ESI, FAB, MS/MS, } \\
\text { MALDI-TOF) }\end{array}$ & \\
\hline Peptides synthesis & $\begin{array}{l}\text { chemical synthesis } \\
\text { recombinant DNA technology } \\
\text { enzymatic synthesis }\end{array}$ & $\begin{array}{l}\text { chemical synthesis (liquid phase) } \\
\text { recombinant DNA technology }\end{array}$ \\
\hline
\end{tabular}

Information adapted from references: Carrasco-Castilla et al. [2012], Korhonen and Pihlanto [2006, 2007], Langevin et al. [2012], Minkiewicz and Dziuba [2009]. 

aspects. Acta Sci. Pol., Technol. Aliment. 13(1), 5-25.

and thermolysin, as well as enzymes of microbiological origin are also used to produce bioactive peptides from various proteins [Kilara and Panayam 2003, Korhonen and Pihlanto 2003]. Many microorganisms found in dairy starter cultures are highly proteolytic. Their proteolytic systems consist of cell wall-bound proteinases and numerous intracellular proteinases, among them endopeptidases, aminopeptidases, tripeptidases and dipeptidases [Christensen et al. 1999]. Examples of bioactive peptides released by microbiological enzymes from milk proteins are shown in Table 3 [Korhonen and Pihlanto 2006, Nielsen et al. 2009].

The majority of bioactive peptides released from proteins and found in processed foods are characterised by antihypertensive, antioxidant, antimicrobial, immunomodulatory and mineral binding activity. Carrasco-Castilla et al. [2012] discussed various methods for evaluating the five types of activity of peptides released by protein hydrolysis. IPP and VPP peptides are generally described and analysed as inhibitors of the angiotensin I-converting enzyme, one of the key factors controlling blood pressure [Panchaud et al. 2012]. Their inhibitory capacity is determined by spectrophotometry combined with HPLC, and fluorimetric methods are also applied. The antihypertensive effects of food products containing peptides have been studied in vivo in rats. The antioxidant properties of peptides have been researched extensively during in vitro chemical and biological studies [Antolovich et al. 2002], in vivo experiments on animals and clinical trials involving biomarkers [Karadag et al. 2009]. Antimicrobial peptides and foods containing such peptides may be used as antibacterial, antiviral and antifungal agents. Their efficacy is determined by identifying

Table 3. Bioactive peptides released from milk proteins by proteolytic enzymes of different microorganisms

\begin{tabular}{|c|c|c|c|}
\hline Microorganism & Precursor protein & Peptide sequence & Bioactivity \\
\hline 1 & 2 & 3 & 4 \\
\hline $\begin{array}{l}\text { Lactobacillus helveticus } \\
\text { Sacchoromyces cerevisiae }\end{array}$ & $\beta$-casein, $\chi$-casein & Val-Pro-Pro, Ile-Pro-Pro & $\begin{array}{l}\text { ACE inhibitor, } \\
\text { antihypertensive }\end{array}$ \\
\hline $\begin{array}{l}\text { Lactobacillus GG enzymes } \\
+ \text { pepsin and trypsin }\end{array}$ & $\beta$-casein, $\alpha_{\mathrm{s} 1}$-casein & $\begin{array}{l}\text { Tyr-Pro-Phe-Pro, Ala-Val-Pro-Tyr-Pro- } \\
\text {-Gln-Arg, Thr-Thr-Met-Pro-Leu-Trp }\end{array}$ & $\begin{array}{l}\text { opioid, ACE inhibitor, } \\
\text { immunostimulating }\end{array}$ \\
\hline Lb. helvetcius $\mathrm{CP} 90$ proteinase & $\beta$-casein & Lys-Val-Leu-Pro-Val-Pro-(Glu) & ACE inhibitor \\
\hline Lb. helveticus $\mathrm{CPN} 4$ & whey proteins & Tyr-Pro & ACE inhibitor \\
\hline $\begin{array}{l}\text { Lb. delbrueckii ssp. bulgaricus SS1 } \\
\text { Lactococcus lactis ssp. cremoris FT4 }\end{array}$ & $\beta$-casein, $\chi$-casein & many fragments & ACE inhibitor \\
\hline Lb. delbrueckii ssp. bulgaricus IFO13953 & $\chi$-casein & $\begin{array}{l}\text { Ala-Arg-His-Pro-His-Pro-His-Leu- } \\
\text {-Ser-Phe-Met }\end{array}$ & antioxidative \\
\hline $\begin{array}{l}\text { Lb. rhamnosus }+ \text { hydrolysis } \\
\text { with pepsin and Colorase PP }\end{array}$ & $\beta$-casein & $\begin{array}{l}\text { Asp-Lys-Ile-His-Pro-Phe, } \\
\text { Tyr-Gln-Glu-Pro-Val-Leu, } \\
\text { Val-Lys-Glu-Ala-Met-Ala-Pro-Lys }\end{array}$ & $\begin{array}{l}\text { ACE inhibitor } \\
\text { antioxidative }\end{array}$ \\
\hline Lb. delbrueckii ssp. bulgaricus & $\beta$-casein & $\begin{array}{l}\text { Ser-Lys-Val-Tyr-Pro-Phe-Pro-Gly- } \\
\text { Pro-Ile }\end{array}$ & ACE inhibitor \\
\hline $\begin{array}{l}\text { Streptococcus thermophilus }+ \text { Lc. lactis } \\
\text { ssp. lactis biovar. diacetylactis }\end{array}$ & $\beta$-casein & Ser-Lys-Val-Tyr-Pro & ACE inhibitor \\
\hline Lb. helveticus ICM 1004 - extract & $\begin{array}{l}\text { hydrolysate } \\
\text { of non-fat milk }\end{array}$ & Val-Pro-Pro, Ile-Pro-Pro & ACE inhibitor \\
\hline $\begin{array}{l}\text { Lc. lactis ssp. lactis } 3923 \text { and Lc. lactis } \\
\text { ssp. cremoris F3 }\end{array}$ & $\alpha_{\mathrm{s} 1}$-casein & Arg-Pro-Lys-His-Pro-Ile-Lys-His-Gln & ACE inhibitor \\
\hline
\end{tabular}


Dziuba B., Dziuba M., 2014. Milk proteins-derived bioactive peptides in dairy products: molecular, biological and methodological aspects. Acta Sci. Pol., Technol. Aliment. 13(1), 5-25.

Table 3 - cont.

\begin{tabular}{|c|c|c|c|}
\hline 1 & 2 & 3 & 4 \\
\hline $\begin{array}{l}\text { Lc. lactis ssp. lactis } 3923 \text { and Lc. lactis } \\
\text { ssp. cremoris F } 3\end{array}$ & $\beta$-casein & Ser-Lys-Val-Leu-Pro-Val-Pro-Glu & ACE inhibitor \\
\hline $\begin{array}{l}\text { Lc. lactis ssp. lactis } 3923 \text { and Lc. lactis } \\
\text { ssp. cremoris F3 }\end{array}$ & $\beta$-casein & $\begin{array}{l}\text { Leu-Leu-Tyr-Gln-Glu-Pro-Val-Leu- } \\
\text {-Gly-Pro-Val-Arg-Gly-Pro-Phe-Pro- } \\
\text {-Ile-Ile-Val }\end{array}$ & immunomodulating \\
\hline Lb. helveticus 1198 & $\beta$-casein & Val-Ser-Lys-Val-Lys-Glu-Ala & ACE inhibitor \\
\hline Lb. helveticus 1198 & $\beta$-casein & $\begin{array}{l}\text { Met-Ala-Pro-Lys-His-Lys-Glu-Met- } \\
\text {-Pro-Phe-Pro-Lys-Tyr-Pro-Val-Glu- } \\
\text {-Pro-Phe }\end{array}$ & ACE inhibitor \\
\hline Lb. helveticus 1198 & $\beta$-casein & $\begin{array}{l}\text { Val-Leu-Gly-Pro-Val-Arg-Gly-Pro- } \\
\text {-Phe-Pro-Ile-Ile-Val }\end{array}$ & ACE inhibitor \\
\hline Lb. helveticus 1198 & $\beta$-casein & $\begin{array}{l}\text { Leu-Val-Tyr-Pro-Phe-Pro-Gly-Pro- } \\
\text {-Ile-His-Asn-Ser-Leu-Pro-Gln-Asn- } \\
\text {-Ile-Pro-Pro-Leu-Thr-Gln-Thr-Pro- } \\
\text {-Val-Val-Val-Pro-Pro-Phe }\end{array}$ & ACE inhibitor \\
\hline
\end{tabular}

Information adapted from references: Korhonen and Pihlanto [2006], Nielsen et al. [2009].

minimum concentrations that inhibit the proliferation of a given group of microorganisms [Najafian and Babji 2012]. Phosphopeptides, which are casein derivatives, can form soluble salts, organic phosphate derivatives, which participate in the transport and absorption of divalent cations, in particular calcium. The above processes play an important role in bone tissue reconstruction and prevention of dental diseases [Adt et al. 2011]. Ability of peptides to bind minerals is determined by conductometric titration of free calcium and spectrophotometric methods [Hansen et al. 1997]. Assays aiming to determine the immunomodulatory properties of peptides have to account for a variety of factors (susceptibility to digestion in the gastrointestinal tract, peptides' effect on the mucosal immune system, toxicity), therefore, they often deliver controversial results. Most studies investigating the immunomodulatory properties of peptides evaluate their influence on lymphocyte activity and proliferation, cytokinin secretion and the production of antibodies [Durrieu et al. 2006, Gautier et al. 2006, Stuknyte et al. 2011].

\section{COMMERCIALLY AVAILABLE FOODS AND INTERMEDIATE PRODUCTS CONTAINING BIOACTIVE PEPTIDES DERIVED FROM MILK PROTEINS}

Significant progress has been made in laboratory research investigating bioactive peptides in protein hydrolysates [Carrasco-Castilla et al. 2012]. Conventional and unconventional sources of peptides from protein hydrolysates have been identified, the functions (functional peptides) and physiological significance of peptides have been described. Foods containing bioactive peptides from protein hydrolysis have been approved for mass consumption by health authorities, nevertheless, their availability on the market continues to be limited. Researchers show a growing interest in bioactive peptides, which could imply that the choice of functional foods on the consumer market will grow steadily in the near future. Bioactive peptides are already used in the production of functional foods, including nutraceuticals [Mils et al. 2011, Phelan et al. 2009]. Table 4 [Carrasco-Castilla et al. 2012, Korhonen and Pihlanto 2006, Mils et al. 2011] 
Dziuba B., Dziuba M., 2014. Milk proteins-derived bioactive peptides in dairy products: molecular, biological and methodological aspects. Acta Sci. Pol., Technol. Aliment. 13(1), 5-25.

Table 4. Commercial milk products and semi products with health or functional properties, containing bioactive peptides

\begin{tabular}{|c|c|c|c|}
\hline Product, manufacturer & Product type & Bioactive peptides & $\begin{array}{c}\text { Claimed pro-health/functional } \\
\text { effect }\end{array}$ \\
\hline 1 & 2 & 3 & 4 \\
\hline $\begin{array}{l}\text { Calpis } \\
\text { Calpis Co., Japan }\end{array}$ & sour milk & $\begin{array}{l}\text { Val-Pro-Pro, Ile-Pro-Pro } \\
\text { from } \beta \text {-casein and } \kappa \text {-casein }\end{array}$ & lowering of blood pressure \\
\hline $\begin{array}{l}\text { Evolus } \\
\text { Valio Oy, Finland }\end{array}$ & $\begin{array}{l}\text { fermented milk product } \\
\text { enriched with calcium }\end{array}$ & $\begin{array}{l}\text { Val-Pro-Pro, Ile-Pro-Pro } \\
\text { from } \beta \text {-casein and } \kappa \text {-casein }\end{array}$ & lowering of blood pressure \\
\hline $\begin{array}{l}\text { BioZate } \\
\text { Davisco, USA }\end{array}$ & $\begin{array}{l}\text { hydrolysed isolate of } \\
\text { whey proteins }\end{array}$ & $\beta$-lactoglobulin fragments & lowering of blood pressure \\
\hline $\begin{array}{l}\text { BioPURE-GMP } \\
\text { Davisco, USA }\end{array}$ & whey proteins isolate & $\begin{array}{l}\text { א-casein f(106-169) } \\
\text { (glycomacropeptide) }\end{array}$ & $\begin{array}{l}\text { prevent dental caries, influence } \\
\text { blood coagulability, } \\
\text { antiviral, antibacterial }\end{array}$ \\
\hline $\begin{array}{l}\text { PRODIET F200/Lactium } \\
\text { Ingredia, France }\end{array}$ & $\begin{array}{l}\text { flavoured milk product, } \\
\text { confectionery, capsules }\end{array}$ & $\begin{array}{l}\text { Tyr-Leu-Gly-Tyr-Leu-Glu- } \\
\text {-Gln-Leu-Leu-Arg } \\
\alpha_{\mathrm{S} 1} \text {-casein } \mathrm{f}(91-100)\end{array}$ & stress release effect \\
\hline $\begin{array}{l}\text { Festivo } \\
\text { MTT Agrifood Research, Finland }\end{array}$ & $\begin{array}{l}\text { hard cheese with reduced } \\
\text { fat content }\end{array}$ & $\begin{array}{l}\alpha_{\mathrm{S} 1} \text {-casein } \mathrm{f}(1-9), \alpha_{\mathrm{S} 1} \text {-casein } \\
\mathrm{f}(1-7), \alpha_{\mathrm{S} 1} \text {-casein } \mathrm{f}(1-6)\end{array}$ & no effect \\
\hline $\begin{array}{l}\text { Peptides containing cystein } \\
\text { DMV International, Holland }\end{array}$ & component hydrolysate & peptides from milk & $\begin{array}{l}\text { helps to sleep well and be full of } \\
\text { energy }\end{array}$ \\
\hline $\begin{array}{l}\text { C12 } \\
\text { DMV International, Holland }\end{array}$ & component hydrolysate & peptides from caseins & lowering blood pressure \\
\hline $\begin{array}{l}\text { Capolac } \\
\text { Arla Foods Ingredients, Sweeden }\end{array}$ & component & caseinophosphopeptides & helps to absorb minerals \\
\hline $\begin{array}{l}\text { PeptoPro } \\
\text { DSM Food Specialties, Norway }\end{array}$ & component hydrolysate & peptides from caseins & $\begin{array}{l}\text { improvement of muscle strength } \\
\text { and physical exercise capacity }\end{array}$ \\
\hline $\begin{array}{l}\text { Vivinal Alpha } \\
\text { Borculo Domo Ingredients } \\
\text { (BDI), Norway }\end{array}$ & component hydrolysate & peptides from whey proteins & helps to relax and sleep \\
\hline $\begin{array}{l}\text { Casein DP Peptio Drink } \\
\text { Kanebo, Japan }\end{array}$ & drink & $\begin{array}{l}\text { decapeptide from caseins } \\
\text { FFVAPFPEVFGK } \\
\text { FFVAPFPEVFGK }\end{array}$ & lowering of blood pressure \\
\hline $\begin{array}{l}\text { Tekkotsu Inryou } \\
\text { Suntory, Japan }\end{array}$ & drink & $\begin{array}{l}\text { phosphopeptides } \\
\text { from caseins }\end{array}$ & helps to absorb minerals \\
\hline $\begin{array}{l}\text { Kotsu Kotsu calcium } \\
\text { Asahi, Japan }\end{array}$ & drink & $\begin{array}{l}\text { phosphopeptides } \\
\text { from caseins }\end{array}$ & helps to absorb minerals \\
\hline $\begin{array}{l}\text { CE90CPP } \\
\text { DMV International, Holland }\end{array}$ & component & $\begin{array}{l}\text { phosphopeptides } \\
\text { from caseins }\end{array}$ & helps to absorb minerals \\
\hline $\begin{array}{l}\text { Glutamine peptides } \\
\text { DMV International, Holland }\end{array}$ & milk proteins hydrolysate & peptides reach in glutamine & immunomodulating properties \\
\hline $\begin{array}{l}\text { Recaldent } \\
\text { Cadbury Enterprises Pte Ltd. }\end{array}$ & chewing gum & $\begin{array}{l}\text { phosphopeptides } \\
\text { from caseins }\end{array}$ & prevent dental caries \\
\hline
\end{tabular}


Table 4 - cont.

\begin{tabular}{llll}
\hline \multicolumn{1}{c}{1} & \multicolumn{1}{c}{2} & \multicolumn{1}{c}{3} & \multicolumn{1}{c}{ lowering of blood pressure } \\
$\begin{array}{l}\text { Evolus Double Effect Spread, } \\
\text { Valio, Finland }\end{array}$ & margerine & peptides from milk & improve memory, helps to fall \\
$\begin{array}{l}\text { Alphalactalbumin } \\
\text { Davisco, USA }\end{array}$ & whey proteins isolate & $\alpha$-lactalbumin & asleep \\
$\begin{array}{l}\text { Amealbp, Ameal peptide; Calpis } \\
\text { Co., Japan }\end{array}$ & pils, components & $\begin{array}{l}\text { VPP, IPP from } \beta- \\
\text { and } \kappa \text {-casein }\end{array}$ & lowering of blood pressure \\
$\begin{array}{l}\text { GC tooth mousse, } \\
\text { GC Europe N.V. }\end{array}$ & caseinophosphopeptides & prevent dental caries \\
$\begin{array}{l}\text { Lacprodan ALPHA-20 } \\
\text { Arla Foods Ingredients, Sweden }\end{array}$ & components & $\alpha$-lactalbumine (60\%) & $\begin{array}{l}\text { alleviates the symptoms of ulcer } \\
\text { desease }\end{array}$ \\
$\begin{array}{l}\text { MI paste / MI paste plus } \\
\text { Trident extra care } \\
\text { Cadbury Adams, USA }\end{array}$ & toothpaste & caseinophosphopeptides & prevent dental caries \\
\hline
\end{tabular}

Information adapted from references: Carrasco-Castilla et al. [2012], Korhonen and Pihlanto [2006], Mils et al. [2011].

lists commercially available functional and healthpromoting foods and intermediate products which contain bioactive peptides derived from milk proteins and which claim to have antihypertensive, antimicrobial, mineral-binding and anticarcinogenic properties. On the industrial scale, bioactive peptides are used in dairy products (Calpis, Evolus, Peptide Soup EX), toothpaste, chewing gum (MI Paste, Trident Xtra Care) and food supplements (Capolac MM0525, Lacprodan, Recaldent, Ameal peptide, Ameal bp). Two fermented milk products with antihypertensive claims, Calpis and Evolus, have been tested extensively on rats and in clinical trials [Hata et al. 1996, Mizushima et al. 2004, Sepio et al. 2003]. Those products are classified as functional foods. They contain peptides IPP, VPP and LKPNM which have been thoroughly researched and claimed as safe for consumption.

Although peptides carry a great potential as food supplements, they cannot always be included in food products. In some cases, additional safety information may be required regarding the potential toxicity, cytotoxicity and allergenicity of bioactive peptides [Phelan et al. 2009]. Maeno et al. [2005] found that casein-derived products and Val-Pro-Pro peptides from fermented milk powder did not exhibit toxic activity. The above authors argued that there is no need to determine LOEL (lowest observed effect level) or MTD (maximally tolerated dose) doses of the analysed products which were set at more than $2 \mathrm{~g}^{\text {per kg }}{ }^{-1} \mathrm{BW}$ per day ${ }^{-1}$ in a 28 -day study of rats. They concluded that in experiments of the type, MTD and NOEL (no observed effect level) doses for casein hydrolysate powder administered once daily for 13 weeks exceeded $1 \mathrm{~g}$ per $\mathrm{kg}^{-1} \mathrm{BW}$ per day ${ }^{-1}$ and for Val-Pro-Pro and Ile-ProPro - more than $6 \mathrm{mg}$ per $\mathrm{kg}^{-1} \mathrm{BW}$ per day ${ }^{-1}$ [Mizuno et al. 2005]. To date, Val-Pro-Pro and Ile-Pro-Pro have not been found to exert toxic effects. The cited authors also demonstrated that fermented milk containing ValPro-Pro and Ile-Pro-Pro casein-derived tripeptides did not affect the reproductive ability of rats (NOAEL, no observed adverse effect level). The NOAEL dose for fermented milk in reference to the reproductive parameters of female and male rats exceeded $2 \mathrm{~g}$ per $\mathrm{kg}^{-1} \mathrm{BW}^{-1}$ per day ${ }^{-1}$, which is equivalent to $3.3 \mathrm{mg}$ of Val-Pro-Pro and Ile-Pro-Pro per $\mathrm{kg}^{-1} \mathrm{BW}^{-1}$ per day ${ }^{-1}$. Similar NOAEL values were reported by Dent et al. [2007] in a study of rabbits and rats administered lactotripeptide in the prenatal or postnatal period. 


\section{RESEARCH INTO BIOACTIVE PEPTIDES IN DAIRY PRODUCTS}

Butikofer et al. [2007] determined the content of Val-Pro-Pro and Ile-Pro-Pro tripeptides in traditional cheese by HPLC with triplet state mass spectrometry. Those peptides are ACE inhibitors which lower blood pressure. The values of $\mathrm{IC}_{50}$, cheese concentrations in a test solution, which inhibit ACE activity by $50 \%$ were calculated in an in vitro study and expressed in $\mathrm{mg}$ of cheese $\mathrm{mL}^{-1}$. The content of Val-Pro-Pro and Ile-Pro-Pro was determined at $2-224 \mathrm{mg}$ and $0.8-95$ $\mathrm{mg}$, respectively, in hard cheese, $1-120 \mathrm{mg}$ and $1.5-$ $65 \mathrm{mg}$, respectively, in semi-hard cheese, and $0.4-11$ $\mathrm{mg}$ and $0-11 \mathrm{mg}$, respectively, in soft cheese. The authors carried out an in vitro study and concluded that $\mathrm{IC}_{50}$ values determined in vitro cannot be regarded as specific markers for describing the potential activity of the ACE inhibitor in various types of cheese in vivo. Clinical tests are needed to establish ACE inhibitor's antihypertensive properties.

Ortiz-Chao et al. [2009] hydrolysed $\beta$-lactoglobulin $(\beta-\mathrm{Lg})$ with $\mathrm{N}$ Amano protease (enzyme produced by B. subtilis) to obtain the Ser-Ala-Pro-Leu-Arg-Val-Tyr heptapeptide whose sequence corresponds to fr. 36-42 $\beta$-Lg. ACE's inhibitory activity, expressed by the value of $\mathrm{IC}_{50}$, was determined at $8 \mathrm{mM}$, and it was higher than in any of the identified inhibitors with $\beta$-Lg precursors. The activity of Ala-Leu-Pro-Met-His-Ile-Arg (fr. 142-148) and Leu-Gln-Lys-Trp (fr. 74-77) peptides, expressed by $\mathrm{IC}_{50}$, was determined at 42.6 and $34.7 \mathrm{mM}$, respectively. An in vitro study demonstrated that heptapeptides (fr. 142-148) can be hydrolysed by chymotrypsin during digestion [Roufik et al. 2006].

Otte et al. [2011] analysed peptide profiles of fermented milk products containing Lactobacillus helveticus and Lacctococcus lactis strains. They determined the presence of peptides, ACE inhibitors derived mainly from $\beta$-casein and, in smaller quantities, from $\mathrm{a}_{\mathrm{s} 1}$ - and $\kappa$-casein. Fermentation temperature (Lc. lactis $-27,30$ and $33^{\circ} \mathrm{C}$, optimal temperature of approximately $30^{\circ} \mathrm{C}$; Lb. helveticus $-33,37$ and $40^{\circ} \mathrm{C}$, optimal temperature above $40^{\circ} \mathrm{C}$ ) significantly influenced bacterial proliferation, the extent of lysis and ACE's inhibitory activity. Moslehishad et al. [2013] studied ACE inhibitory and antioxidant peptides in bovine and camel milk fermented with the use of Lactobacillus rhamnosus PTCC 1637 bacteria. Peptides released from camel milk proteins were characterised by higher ACE inhibitory activity and antioxidant activity than those derived from bovine milk proteins. The above can be attributed to a higher content of proline residues in camel milk proteins.

Uenishi et al. [2012] isolated the Leu-Pro-Gln-Asn-Ile-Pro-ProLeu (fr. $\beta$-casein 70-77) octapeptide with the ability to inhibit dipeptidyl peptidase-4 (DPP) $\left(\mathrm{IC}_{50} \leq 200 \mu \mathrm{M}\right)$ from gouda cheese. DPP 4 inhibitors play an important role in controlling insulin levels, and they contribute to glucose tolerance in type 2 diabetes. The discussed protocol was used in many research studies of animals [Reimer et al. 2002, Sudre et al. 2002, Yasuda et al. 2004] and humans [Ahrén et al. 2004]. In a study of rats, an octapeptide isolated from gouda cheese was administered orally at $30 \mathrm{mg} / 100 \mathrm{~g}$ BW to demonstrate its beneficial effect on glucose tolerance. The inhibitory potential of the analysed peptide was 100-times lower in comparison with commercially available preparations.

Martinez et al. [2010] studied the gelation of a mixture of casein macropeptide (CMP), a C-terminal fragment of $\kappa$-casein containing 64 amino acids which is released by chymosin or pepsin, with $\beta$-lactoglobulin. They observed that synergistic interactions between CMP and $\beta-\mathrm{Lg}$ in aqueous solutions with the $\mathrm{pH}$ of 3.5-7 promote intensive gelation. Their findings can be used in the production of molecular foods and food products containing CMP as a bioactive ingredient. The biological activity of CMP has been reviewed extensively by Thomä-Worringer et al. [2006]. CMP binds cholera enterotoxins and Escherichia coli, it inhibits bacterial and viral adhesion, demonstrates immunomodulatory activity, supports the proliferation of bifidobacteria, inhibits gastric juice secretion and regulates blood flow.

\section{CONCLUSIONS}

Milk is a rich source of biologically active compounds which can be used in the production of functional foods. Contemporary consumers have a growing interest in foods which are not only a source of basic nutrition, but which also delay and alleviate the consequences of lifestyle diseases. A sound knowledge of the biological properties of milk compounds is 
needed to design such food. It should be noted, however, that the physiological activity of many bioactive milk components has been analysed mostly in in vitro studies and experiments conducted on animals, but never on humans. The development of economically feasible industrial methods for the production of bioactive milk components poses a new challenge for food scientists and food technology experts. Although the potential of milk proteins and peptides for the formulation of functional foods has been long demonstrated, they are still not mass produced. New research efforts are undertaken to optimize the activity of milk proteins and peptides in nutrition and their availability in the human body.

The choice of foods containing biologically active peptides continues to be limited. Newly identified peptides will be introduced to the food processing industry with the advent of new technologies, such as membrane separation, nanofiltration and ultrafiltration. Macroencapsulation and nanoencapsulation methods supply new solutions that improve peptide stability in foods and during digestion.

Future research should focus on the content and biological availability of peptides, milk protein derivatives, in food. Further studies with application of proteomic, peptidomic and metabolomic method are required to investigate the physiological mechanisms responsible for the biological activity of peptides. The process of enriching foods with peptides can also give rise to legal concerns when health claims are made on the resulting end products.

\section{REFERENCES}

Adt I., Dupas C., Boutrou R., Oulahal N., Noel C., Mollé D., Jouvet T., Degraeve P., 2011. Identification of caseinophosphopeptides generated through in vitro gastrointestinal digestion of Beaufort cheese. Int. Dairy J. 21, 129-134.

Ahrén B., Gomis R., Standl E., Mills D., Schweitzer A., 2004. Twelve- and 52-week efficacy of the dipeptidyl peptidase IV inhibitor LAF237 in metformin-treated patients with type 2 diabetes. Diab. Care 27, 2874-2880.

Alexander L.J.., Stewart A.F., MacKinlay A.G., Kapelinskaya T.V., Tkach T.M., Gorodetsky S.I., 1988. Isolation and characterization of the bovine $\kappa$-casein gene. Eur. J. Biochem. 178, 395-401.
Antolovich M., Prenzler P., Patsalides E., McDonald S., Robards K., 2002. Methods for testing antioxidant activity. Analyst 127, 183-198.

Brignon G., Ribadeau-Dumas B., 1973. Localization of the Glu-Gln substitution diff erentiating B and D genetic variants in the peptide chain of bovine beta lactoglobulin. FEBS Lett. 33, 73- 76.

Brignon G., Ribadeu-Dumas B., Mercie J.-C., Pelissier J.P., Das B.C., 1977. Complete amino acid sequence of bovine $\alpha_{\mathrm{s} 2}$-casein. FEBS Lett. 76, 274-279.

Butikofer U., Meyer J., Siebers R., Wechsler D., 2007. Quantification of the angiotensin-converting enzyme-inhibiting tripeptides Val-Pro-Pro and Ile-Pro-Pro in hard, semi-hard and soft cheeses. Int. Dairy J. 17, 968-975.

Carrasco-Castilla J., Hernández-Álvarez A.J., Jiménez-Martínez C., Gutiérrez-López G.F., Dávila-Ortiz G., 2012. Use of proteomics and peptydomics methods in food bioactive peptide science and engineering. Food Eng. Rev. 4, 224-243.

Carter D.C., Ho J.X., 1994. Structure of serum albumin. Adv. Protein Chem. 45, 153-203.

Cavaletto M., Giuffrida M.G., Conti A., 2008. Milk fat globule membrane components - a proteomic approach. Adv. Experim. Med. Biol. 606, 129-141.

Chabance B., Marteau P., Rambaud J.C., Migliore-Samour D., Boynard M., Perrotin P., Guillet R., Jollès P., Fiat A.M., 1998. Casein peptide release and passage to the blood in humans during digestion of milk or yoghurt. Biochimie 80, 155-165

Christensen J.E., Dudley E.G., Pedersen J.A., Steele J.L., 1999. Peptidases and amino acid catabolism in lactic acid bacteria. Antonie van Leeuwenhoek 76, 217-246.

Conti A.L., Napolitano L., Cantisani A.M., Davoli R., Dall'Olio S., 1988. Bovine $\beta$-lactoglobulin H: Isolation by preparative isoelectric focusing in immobilized $\mathrm{pH}$ gradients and preliminary characterization. J. Biochem. Biophys. Meth. 16, 205-214.

Dent M.P., O’Hagana S., Braun W.H., Schaetti P., Marburger A., Vogel O., 2007. A 90-day subchronic toxicity study and reproductive toxicity studiem on ACE inhibition of lactotri-peptide. Food Chem. Toxicol. 45, 1468-1477.

Dong C., Ng-Kwai-Hang K.F., 1998. Characterization of a non-electrophoretic genetic variant of $\beta$-casein by peptide mapping and mass spectrometric analysis. Int. Dairy J. 8, 967-972.

Durrieu C., Degraeve P., Chappaz S., Martial-Gros A., 2006. Immunomodulating effects of water-soluble extracts of traditional French Alps cheese on a human T-lymphocyte cell line. Int. Dairy J. 16, 1505-1514. 
Dziuba J., 1986. Molecular and coloidal aspects of micellar casein structure. Post. Biochem. 32, 335-352

Dziuba J., 2005. Research strategy for proteins and bioactive peptides. In: Enzymatic modification of food components. Eds E. Kołakowski, W. Bednarski, S. Bielecki. Wyd. AR Szczecin, 219-237.

Dziuba J., Iwaniak A., Niklewicz M., 2003. Database of protein and bioactive peptide sequences - BIOPEP. [online], www.uwm.edu.pl/biochemia.

Dziuba J., Kostyra H., Dziuba M., 2012. Food biochemistry: (methods, assignments and tests). 1.15. Bioinformatic methods used in the study of bioactive proteins and peptides - database of bioactive proteins and peptides BIOPEP. Wyd. UWM Olsztyn, 102-113.

Dziuba J., Minkiewicz P., Nałęcz D., Iwaniak A., 1999. Database of biologically active peptide sequences. Nahrung 43, 190-195.

Dziuba M., Darewicz M., 2007. Food proteins as precursors of bioactive peptides - division into families. Food Sci. Technol. Int. 13, 393-404.

Dziuba M., Dziuba B., 2009. In silico analysis of bioactive peptides. In: Bioactive proteins and peptides as funtional foods and nutraceuticals. Eds Y. Mine, E. Li-Chan, B. Jiang. Blackwell Publ. Inst. Food Techn. 325-340.

Dziuba M., Dziuba B., Iwaniak A., 2009. Milk proteins as the source of bioactive peptides. Acta Sci. Pol., Techn. Aliment. 8, 71-90.

Dziuba M., Dziuba J., Minkiewicz P., 2006. Design of food protein proteolysis with a view to obtaining bioactive peptides. Pol. J. Natur. Sci. 21, 999-1020.

Eads T.M., 1994. Molecular origins of structure and functionality in foods. Trends Food Sci. Technol. 5, 147-159.

Eigel W.N., Butler J.E., Ernstom C.A., Farrell H.M. Jr., Harwalkar V.R., Jenness J., Whitney R.M., 1984. Nomenclature of protein of cow's milk: Fifth revision. J. Dairy Sci. 67, 1599-1631.

Expósito I.L., Recio I., 2006. Antibacterial activity of peptides and folding variants from milk proteins. Int. Dairy J. 16, 1294-1305.

Farrell H.M. Jr., Jimenez-Flores R., Bleck G.T., Brown E.M., Butler J.E., Creamer L.K., Hicks C.L., Hollar C.M., Ng-Kwai-Hang K.F., Swaisgood H.E., 2004. Nomenclature of the proteins of cows' milk - Sixth revision. J. Dairy Sci. 87, 1641-1674.

Ferranti P., Traisci M.V., Picariello G., Nasi A., Boschi V., Siervo M., Falconi C., Chianese L., Addeo F., 2004. Casein proteolysis in human milk: tracing the pattern of casein breakdown and the formation of potential bioactive peptides. J. Dairy Res. 71, 74-87.

FitzGerald R.J., Murray B.A., 2006. Bioactive peptides and lactic fermentations. Int. J. Dairy Technol. 59, 118-125.

FitzGerald R.J., Murray B.A., Walsh D.J., 2004. Hypotensive peptides from milk proteins. J. Nutr. 134, 980S-988S.

Fuller R., 1989. Probiotics in man and animals. J. Appl. Bacter. 66, 365-378.

Gagnaire V., Molle D., Herrouin M., Leonil J., 2001. Peptides identified during emmental cheese ripening: origin and proteolytic systems involved. J. Agric. Food Chem. 49, 407-412.

Gautier S.F., Pouliot Y., Saint-Sauveur D., 2006. Immunomodulatory peptides obtained by the enzymatic hydrolisis of whey proteins. Int. Dairy J. 16, 1315-1323.

Gobbetti M., Stepaniak L., De Angelis M., Corsetti A., DiCagno R., 2002. Latent bioactive peptides in milk proteins: proteolytic activation and significance in dairy processing. Crit. Rev. Food Sci. Nutr. 42, 223-239.

Godovac-Zimmermann J., Krause I., Baranyi M., Fischer-Frühholz S., Juszczak J., Erhardt G., Buchberger J., Klostermeyer H., 1996. Isolation and rapid sequence characterization of two novel bovine $\beta$-lactoglobulins I and J. J. Protein Chem. 15, 743-750.

Godovac-Zimmermann J., Krause I., Buchberger J., Weiss G., Klostermeyer H., 1990. Genetic variants of bovine beta-lactoglobulin. A novel wild-type beta-lactoglobulin $\mathrm{W}$ and its primary sequence. Biol. Chem. Hoppe-Seyler 371, 255-260.

Grosclaude F., 1979. A genetic and biochemical analysis of a polymorphism of bovine $\alpha_{\mathrm{s} 2}$-casein. J. Dairy Res. 46, 211-213.

Grosclaude F., Mahe M.F., Mercie J.C., Ribadeu-Dumas B., 1972. Localization of amino acid substitutions diff erentiating the A and B variants of $\kappa$-casein in cattle. Ann. Génét. Sél. Anim. 4, 515-521.

Grosclaude F., Ribadeau-Dumas B., 1973. Structure primaire de la caseine $\alpha_{\mathrm{s} 1}$ et de la caseine $\beta$-bovine. Eur. J. Biochem. 40, 323-324.

Han S.K., Shin Y.C., Byun H.D., 2000. Biochemical, molecular and physiological characterization of a new $\beta$-casein variant detected in Korean cattle. Anim. Genet. 31, 49-51.

Hansen M., Sandström B., Jansen M., Sǿrensen S.S., 1997. Effect of casein phosphopeptides on zinc and calcium absorption from bread meals. J. Trace Elem. Med., Biolog. 11, 143-149. 
Hata Y., Yamamoto M., Ohni M., Nakajima K., Nakamura Y., Takano T., 1996. A placebo-controlled study of the effect of sour milk on blond pressure in hypertensive subjects. Am. J. Clin. Nutr. 64, 767-771.

Hernández-Ledesma B., Amigo L., Ramos M., Recio I., 2004. Angiotensin converting enzyme inhibitory activity in commercial fermented products. Formation of peptides under simulated gastrointestinal digestion. J. Agricul. Food Chem. 52, 1504-1510.

Horne D.S., 2006. Casein micelle structure: models and muddles. Curr. Opin. Coll. Interface Sci. 11, 148-153.

Iwaniak A., 2011. Analysis of relationships between yhe structure of peptides derived from food proteins and their activity to inhibit the angiotensin converting enzyme. Evaluation of suitability of the in silico methods in the research concerning protein precursors of bioactive peptides. Wyd. UWM Olsztyn, 1-151.

Jakob E., Puhan Z., 1992. Technological properties of milk as influenced by genetic polymorphism of milk proteins - A review. Int. Dairy J. 2, 157-178.

Karadag A., Ozcelik B., Saner S., 2009. Review of methods to determine antioxidant capacities. Food Anal. Meth. 2, 41-60

Karelin A.A., Blishchenko E.Y., Ivanov V.T., 1998. A novel system of peptidergic regulation. FEBS Lett. 428, 7-12.

Kasai T., Honda T., Kiriyama S., 1992. Caseinophosphopeptides (CPP) in faeces of rats fed casein diet. Biosci. Biotechn. Biochem. 56, 1150-1151.

Kilara A., Panyam D., 2003. Peptides from milk proteins and their properties. Cri. Rev. Food Sci. Nutr. 43, 607-633.

Korhonen H., Pihlanto A., 2003. Food-derived bioactive peptides - opportunities for designing future foods. Curr. Pharm. Design 9, 1297-1308.

Korhonen H., Pihlanto A., 2006. Bioactive peptides: Production and functionality. Int. Dairy J. 16, 945-960.

Korhonen H., Pihlanto A., 2007. Technological options for the production of health-promoting proteins and peptides derived from milk and colostrum. Curr. Pharm. Des. 13, 829-843.

Kuhn N.J., Carrick D.T., Wilde C.J., 1980. Lactose synthesis: Possibilities of regulation. J. Dairy Sci. 63, 328-336.

Kumosinski T.F., Brown E.M., Farrell H.M. Jr., 1993. Three-dimensional molecular modeling of bovine caseins: Energy minimized $\beta$-casein structure. J. Dairy Sci. 76, 931-945.

Langevin M-E., Roblet C., Moresowi C., Ramassamy C., Bazinet L., 2012. Comparative application of pressure- and electrically-driven membrane processes for isolation of bioactive peptides from soy protein hydrolysate. J. Membr. Sci. 403-404, 15-24.

Madureira A.R., Pereira C.I., Gomes A.M.P., Pentado M.E., 2007. Bovine whey proteins - Overview on their main biological properties. Food Res. Int. 40, 197-211.

Maeno M., Nakamura Y., Mennear J.H., Bernard B.K., 2005. Studies of the toxicological potential of tri-peptides (Lvalyl-L-prolyl-L-proline and L-iso-leucyl-L-prolyl-Lproline): III. Single- and/or repeated-dose toxicity of tri-peptides-containing Lactobaqcillus Helvetius-fermented milk powder and casein hydrolysate in rats. Int. J. Toxicol. 24, S13-S23.

Mahè M.F., Grosclaude F., 1982. Polymorphisme de la caseine $\alpha_{\mathrm{s} 2}$ des bovines: Characterization $\mathrm{du}$ variant C du yak (Bos grunnies). Ann. Genet. Sel. Anim. 14, 401-416.

Manso M.A., Léonil J., Jan G., Gagnaire V., 2005. Application of proteomics to the characterisation of milk and dairy products. Int. Dairy J. 15, 845-855.

Martinez M.J., Farías M.E., Pilosof A.M.R., 2010. The dynamice of heat gelation of casein glycomacropeptide $\beta$-lactoglobulin mixtures as affected by interactions in the aqueous phase. Int. Dairy J. 20, 580-588.

Meisel H., Frister H., 1989. Chemical characterization of bioactive peptides from in vivo digests of casein. J. Dairy Res. 56, 343-349.

Meisel H., Goepfert A., Guenther S., 1997. ACE-inhibitory activities in milk products. Milchwissen. 52, 307-311.

Mercier J.C., Brignon G., Ribadeau-Dumas B., 1973. Structure primaire de la caseine kappa B bovine. Sequence complete. Eur. J. Biochem. 35, 222-235.

Mercie J.C., Grosclaude F., Ribadeau-Dumas B., 1971. Structure primaire de la caseine $\alpha_{\mathrm{s} 1}$ bovine. Sequence complete. Eur. J. Biochem. 4, 27-31.

Mils S., Ross R.P., Hill C., Fitzgerald G.F., Stanton C., 2011. Milk intelligence: Mining milk for bioactive substances associated with human Heath. Int. Dairy J. 21, 377-401.

Minkiewicz P., Dziuba J., 2009. Production of bioactive and functional peptides. In: Bioactive food proteins and peptides. Eds J. Dziuba, Ł. Fornal. WNT Warszawa, 110-140.

Minkiewicz P., Dziuba J., Iwaniak A., Dziuba M., Darewicz M., 2008. BIOPEP and other programs processing bioactive peptide sequences. J. AOAC Int. 91, 965-980.

Mizuno S., Mennear J.H., Matsuura K., Bernard B.K., 2005. Studies of the toxicological potential of tri-peptides (L-valyl-L-prolyl-L-proline and L-iso-leucyl-L-prolyl-L-proline): V. A 13-week toxicity study of 
tri-peptides-containing casein hydrolysate in male and female rats. Int. J. Toxicol. 24, S41-S59.

Mizushima S., Oshige K., Watanabe J., Kiura M., Kadowaki T., Nakamura Y., Tochikubo O., Ueshima H., 2004. Randomized controlled trial of sour milk on blond pressure in borderline hypertensive men. Am. J. Hypertens. 17, 701-706.

Moslehishad M., Ehsani M.R., Salami M., Mirdamadi S., Ezzatpanah H., Naslaji A.N., Moosavi-Movahedi A.A., 2013. The comparative assessment of ACE-inhibitory and antioxidant activities of peptide fractions obtained from fermented camel and bovine milk by Lactobacillus rhamnosus PTCC 1637. Int. Dairy J. 29, 82-87.

Najafian L., Babji A.S., 2012. A review of fish-derived antioxidant and antimicrobial peptides: their production, assessment and applications. Peptides 33, 178-185.

Nakamura Y., Yamamoto N., Sakai K., Takano T., 1995. Antihypertensive effect of sour milk and peptides isolated from it that are inhibitors to angiotensin-I-converting enzyme. J. Dairy Sci. 78, 1253-1257.

Narai-Kanayama A., Shikata Y., Hosono M., Aso K., 2010. High level production of bioactive di- and tri-tyrosine peptides by protease-catalysed reactions. J. Biotechnol. 150, 343-347.

Nielsen M.S., Martinussen T., Flambard B., Sǿrensen K.I., Otte J., 2009. Peptide profiles and angiotensin-I-converting enzyme inhibitory activity of fermentem milk products: effect of bacterial strain, fermentation $\mathrm{pH}$, and storage time. Int. Dairy J. 19, 155-165.

Ortiz-Chao P., Gómez-Ruiz J.A., Rastall R.A., Mills D., Kramer R., Pihlanto A., Korhonen H., Jauregi P., 2009. Production of novel ACE inhibitory peptides from $\beta$-lactoglobulin Rusing Protease N Amano. Int. Dairy J. 19, 69-76.

Otte J., Lenhard T., Flambard B., Sǿrensen K.I., 2011. Influence of fermentation temperature and autolysis on ACE-inhibitory activity and peptide profile sof milk fermentem by selected strains of Lactobacillus helveticus and Lactoccocus lactis. 21, 229-238.

Panchaud A., Affolter M., Kossmann M., 2012. Mass spektrometry for nutritional peptidomics: haw to analyze food bioactives and their health effects. J. Proteom. 75, 3546-3559.

Parodi P.W., 2007. A role for milk proteins and their peptides in cancer prevention. Cur. Pharm. Design 13, 813-828.

Parrot S., Degraeve P., Curia C., Martial-Gros A., 2003. In vitro study on digestion of peptides in Emmental cheese: analytical evaluation and influence on angiotensin-I- -converting enzyme inhibitory peptides. Nahrung 47, 87-94.

Permyakov E.A., Berliner L.J., 2000. $\alpha$-Lacalbumin: structure and function. FEBS Lett. 473, 269-274.

Phelan M., Aherne A., FitzGerald R.J., O’Brien N.M., 2009. Casein-derived bioactive peptides: Biological effects, industrial uses, safety aspects and regulatory status. Int. Dairy J. 19, 643-654.

Rammer P., Groth-Pedersen L., Kirkegaard T., Daugaard M., Rytter A., Szyniarowski P., Hǿyer-Hansen M., Povlsen L.K., Nylandsted J., Larsen J.E., Jäättelä M., 2010. BAMLET activates a lysosomal cell death program in cancer cells. Mol. Cancer Ther. 9, 24-32.

Reimer M.K., Horst J.J., Aare'n B., 2002. Long-term inhibition of dipeptydyl peptidase IV improves glucose tolerance and preserves islet function in mice. Eur. J. Endocrinol. 146, 717-727.

Reinhardt T.A., Lippolis J.D., 2008. Developmental changes in the milk fat globule membrane proteome during the transition from colostrum to milk. J. Dairy Sci. 91, 2307-2318.

Roufik S., Gautier S.F., Turgeon S.L., 2006. In vitro digestibility of bioactive peptides derived from bovine $\beta$-lactoglobulin. Int. Dairy J. 16, 294-302.

Saito T., Nakamura T., Kitazawa H., Kawai Y., Itoh T., 2000. Isolation and structural analysis of antihypertensive peptides that exist naturally in Gouda cheese. J. Dairy Sci. 83, 1434-1440.

Sanlidere Algolu H., Öner Z., 2011. Determination of antioxidant activity of bioactive peptide fractions obtained from jogurt. J. Dairy Sci. 94 (11), 5305-5314.

Sepio L., Jauhiainen T., Pyssa T., Korpela R., 2003. A fermented milk high in bioactive peptides has a blood pressure-lowering effect in hypertensive subjects. Am. J. Clin. Nutr. 77, 326-330.

Shimizu M., 2004. Food derived peptides and intestinal functions. BioFactors 21, 43-47.

Simos Y., Metsios A., Verginadis I., D’Alessandro A.-G., Loiudice P., Jirillo E., Charalampidis P., Kouimanis V., Bulaka A., Martemucci G., Karkabounas S., 2011. Antioxidant and anti-platelet properties of milk from goat, donkey and cow: An in vitro, ex vivo and in vivo study. Int. Dairy J. 21, 901-906.

Spitsberg V.L., 2005. Bovine milk fat globule membrane as a potential neutraceutical. J. Dairy Sci. 88, 2289-2294.

Stanton C., Ross R.P., Fitzgerald G.F., Van Sindern D., 2005. fermentem functional foods based on probiotics 
and their biogenic metabolits. Curr. Opinion Biotechnol. 16, 198-203.

Stuknyte M., De Noni I., Gugliemetti S., Minuzzo M., Mora D., 2011. Potental immunomodulatory activity of bovine casein hydrolysates produced after digestion with proteinase of lactic acid bacteria. Int. Dairy J. 21, 763-769.

Sudre B., Broqua P., White R.B., Ashworth D., Evans D.M., Haigh R., Junien J.-L., Aubert M.L., 2002. Chronic inhibition of circulating dipeptidyl peptidase IV FE 999011 delays the occurrence of diabetes in male Zucker diabetic fatty rats. Diabetes 51, 1461-1469.

Svanborg C., Argestam H., Aronson A., Bjerkvig R., Duringer C., 2003. HAMLET kills tumor cells by an apoptosis-like mechanism - cellular, molecular, and therapeutic aspects. Adv. Cancer Res. 88, 1-29.

Svedberg J., de Haas J., Leimenstoll G., Paul F., Teschemacher H., 1985. Demonstration of $\beta$-casomorphin immunoreactive materials in vitro digests of bovine milk and in small intestine contents after bovine milk ingestion in adult humans. Peptides 6, 825-830.

Swaisgood H.E., 1992. Chemistry of caseins. In: Advanced dairy chemistry - I. Proteins. Ed. P.F. Fox. Elsevier Appl. Sci. New York, 63-110.

Swaisgood H.E., 1982. Chemistry of milk proteins. In: Developments in Dairy Chemistry. Ed. P.F. Fox. Applied Sci. Publ. London, 1-59.

Tavares T.G., Contreras M.M., Amorim M., Martin-Alvarez P.J., Pentado M.E., Recio, I., Malcata, F.X., 2011. Optimisation, by response surface methodology, of degree of hydrolysis and antioxidant and ACE-inhibitory activities of whey protein hydrolysates obtained with cardoon extract. Int. Dairy J. 21 (12), 926-933.

Thomä-Worringer C., Sǿrensen J., Fandiňo L., 2006. Health effects and technological features of caseino-macropeptide. Int. Dairy J. 16, 1324-1333.
Uenishi H., Kabuki T., Seto Y., Serizawa A., Nakajima H., 2012. Isolation and identification of casein-derived dipeptydyl-peptidase 4 (DPP-4)-inhibitory peptide LPQNIPPL from gouda-type cheese and its effect on plasma glucose in rats. Int. Dairy J. 22, 24-30.

Vecruysse L., Smagghe G., Van Amerongen A., Ongenaert M., Van Camp J., 2009. Critical Evaluation on the use of bioinformatics as a theoretical tool to find high-potential sources of ACE inhibitory peptides. Peptides 30, 575-582.

Vermeirssen V., Van Camp J., Verstraete W., 2004. Bioavailability of angiotensin-I-converting enzyme inhibitor peptides. Br. J. Nutr. 92, 357-366.

Visser S. Slangen Ch.J., Lagerwert F.M., Van Dongen W.D., Haverkamp J., 1995. Identification of a new genetic variant of bovine $\beta$-casein by reversed-phase highperformance liquid chromatography and mass spectrometric analysis. J. Chromatogr. A, 711, 141-150.

Waugh D.F., 1971. Formation and structure of micelles. In: Milk proteins: chemistry and molecular biology. H.A. McKenzie. Academic Press, New York, 4-85.

Yamasaki Y., Maekawa K., 1978. A peptide with delicious taste. Agric. Biol. Chem. 42, 1761-1765.

Yasuda N., Inoue T., Nagakura T., Yamazaki K., Seaki T., Tanaka I., 2004. Metformin causes reduction of food intake and body weight gain and improvement of glucose intolerance in combination with dipeptidyl peptidase IV inhibitor in Zucker fa/fa rats. J. Pharmacol. Exp. Ther. 310, 614-619.

Zimecki M., Kruzel M.L., 2007. Milk-derived proteins and peptides of potential therapeutic and nutritive value. J. Experim. Therap. Oncol. 6, 89-106. 


\section{PEPTYDY BIOAKTYWNE POCHODZACE Z BIAŁEK MLEKA W PRODUKTACH MLECZARSKICH: ASPEKTY MOLEKULARNE, BIOLOGICZNE I METODOLOGICZNE}

\section{STRESZCZENIE}

Białka są jednym z podstawowych składników żywności, pod względem zarówno żywieniowym, jak i funkcjonalnym. Są źródłem energii, ale przede wszystkim aminokwasów niezbędnych do syntezy białek ustrojowych. Ponadto wiele białek wykazuje specyficzne aktywności biologiczne, które mogą kształtować funkcjonalne lub prozdrowotne właściwości produktów żywnościowych. Te białka i produkty ich hydrolizy (peptydy) mogą również wpływać na właściwości żywności oraz oddziaływać na organizm człowieka. Pomimo że białka mleka są bogatym źródłem peptydów bioaktywnych, niewielka jest liczba dostępnych, handlowych produktów spożywczych z peptydami bioaktywnymi. Obserwowany trend dynamicznego zainteresowania peptydami bioaktywnymi pozwala przypuszczać, że w niedalekiej przyszłości wzrośnie znacząco liczba dostępnych produktów z deklarowaną funkcjonalnością. W pracy scharakteryzowano molekularne oraz biologiczne właściwości białek mleka jako prekursorów peptydów bioaktywnych. Na tym tle przedstawiono strategię ich otrzymywania i badania na skalę zarówno laboratoryjną, jak i przemysłową oraz zakres ich przemysłowego zastosowania. Omówiono również przykłady badań wskazujących możliwości wykorzystania peptydów bioaktywnych, pochodzących z białek mleka, do produkcji nowych produktów, określanych jako nutraceutyki.

Słowa kluczowe: białka mleka, peptydy bioaktywne, hydroliza, produkty z peptydami bioaktywnymi

For citation - Do cytowania

Dziuba B., Dziuba M., 2014. Milk proteins-derived bioactive peptides in dairy products: molecular, biological and methodological aspects. Acta Sci. Pol., Technol. Aliment. 13(1), 5-25. 